\title{
The Impact of the New Accounting Reporting Among Listed Firms in Nigerian Stock Market
}

\author{
Musa Yelwa Abubakar ${ }^{1}$ \\ Nasiru Abdulsallam² \\ Muhammad Yusuf Alkali ${ }^{3}$ (iD

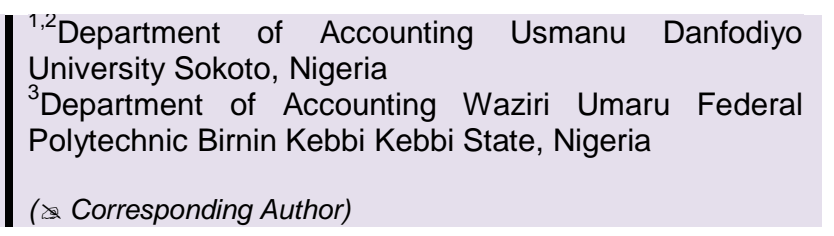

\section{Abstract}

The study discusses the relationship between accounting disclosures and market value under new accounting reporting. The study addresses whether accounting information has improved after the IFRS adoption among Nigerian listed firms. The study adopted Ohlson (1995) stock price model that has commonly been used in the capital market for a 5-year data of 129 companies listed in the Nigerian stock market. The Findings of the study have shown disaggregated assets and liabilities have a strong relationship with stock price. However, there is higher association after the adoption of IFRS from the adjusted $\mathrm{R}^{2}$. Furthermore, current assets presented more explanatory power than all other variables in the model, signifying that investors rely on current assets for decision making. However, Cramer (1987) $\mathrm{Z}$ statistics provided no significance difference in value relevance between the two periods. A possible explanation of the changes could be that investors do not view accounting information to be different in the two periods. Therefore, policy makers, standard setters, and regulators need to come together to address the issue of IFRS adoption by firms in Nigeria.

Keywords: Accounting information, Value relevance, Assets, Liabilities.

JEL Classification: G10, G14, G15.

\section{Contents}

1. Introduction

2. Literature Review ...................... 2

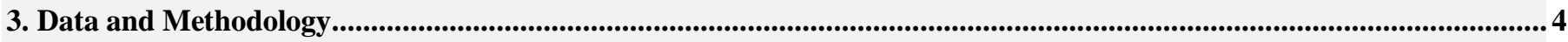

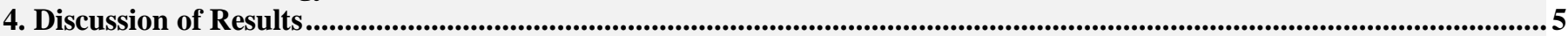

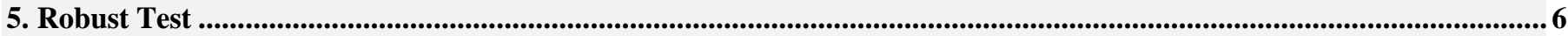

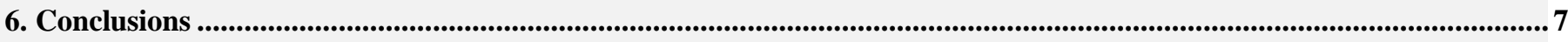

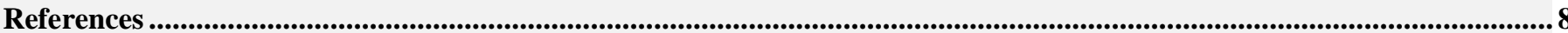

Citation | Musa Yelwa Abubakar; Nasiru Abdulsallam; Muhammad Yusuf Alkali (2017). The Impact of the New Accounting Reporting Among Listed Firms in Nigerian Stock Market. Asian Journal of Social Sciences and Management Studies, 4(1): 1-9.

DOI:

ISSN(E) :

10.20448/journal.500/2017.4.1/500.1.1.9 Crossref

$2313-7401$

2518-0096

This work is licensed under a Creative Commons Attribution 3.0 License (co) EY

Contribution/Acknowledgement: All authors contributed to the conception and design of the study.

Funding: $\quad$ This study received no specific financial support.

Competing Interests: The authors declare that they have no conflict of interests.

Transparency: $\quad$ The authors confirm that the manuscript is an honest, accurate, and transparent account of the study was reported; that no vital features of the study have been omitted; and that any discrepancies from the study as planned have been explained.

History:

Ethical:

Publisher:

Received: 24 August 2016/ Revised: 1 September 2016/ Accepted: 26 September 2016/ Published: 27 October 2016 This study follows all ethical practices during writing. Asian Online Journal Publishing Group 


\section{Introduction}

This study explores the relevance of accounting information on the disaggregated assets and liabilities after the adoption of International Financial Reporting System(IFRS) in Nigeria. The study adopted the most widely used Ohlson (1995) price model to determine whether accounting information is more value relevant after the adoption of IFRS in Nigeria. The motivation of this study is premised on the quality of accounting information reported by the World Bank in the year 2010. The report of the world bank in the period was that Nigerian accounting and auditing reporting suffered a serious neglect, non-update of domestic accounting standard, non-compliance, and disclosures of accounting reporting by the companies. Also, Nigerian stock market is one of the biggest markets in Africa and among the emerging markets in the world, therefore, conducting a study in the market would provide a better understanding of the capital market in emerging market.

Accounting research after Ball and Brown (1968) produced several studies presenting association between market value and accounting earnings. Immediately, after their study, more researchers on value relevance were carried out to include balance sheet disclosures on total assets and total liabilities, income statements, cash flows, and earnings using Ohlson (1995). However, the prior studies on value relevance focused on the US and UK markets only (Barth, 1994; Barth et al., 1996; Barth et al., 1999). The increasing importance of accounting information within the international markets, lead to more studies investigating the value relevance of accounting information in markets that are non-US developed markets (Amir et al., 1993; Collins et al., 1997; Graham et al., 2000) extended to emerging markets (Chen et al., 2001; Kargin, 2013a; Chebaane and Othman, 2014; Mironiuc et al., 2015; Păşcan, 2015) and in Nigeria (Umoren \& Enang 2015; Omokhudu \& Ibadin 2015; Mohammed \& Lode 2015; Muhammad et al. 2015).

The choice for the Nigerian market between the year 2009 to 2011 (pre-adoption) and 2012 to 2013 (after the adoption) is on the fact that, 2009 was the year immediately after the 2008 financial crisis in the country while the period 2012 was the year of IFRS adoption in the country. Another reason for taking Nigeria in Africa was because Nigerian capital market is reported by NSE in 2013 and CIA fact book 2013 to be the second largest capital market after South Africa and the most famous in the West African sub-region. The Nigerian equities market appreciation in 2012 to 2013 made the market be among the best-performing markets in the world (Peter and Nnorom, 2013).

Nigerian capital market is reported to be in a weak-form efficiency, therefore, follows a random walk (Sule et $a l ., 2015)$. The growth of the Nigerian capital market attracted many investors into the capital market, this evident by the increasing number of investors in the economy. The Nigerian domestic bond registration with JP Morgan local currency index in the year 2012 is another milestone for the market. Also, the local bond in Nigeria gets another huge boost in 2013 from the inclusion in the sovereign bonds of Barclay's Emerging bond index. This contributes significantly in attracting foreign investors that have an estimated investment in the country of about USD5.6 billion in Nigerian bonds (Peter and Nnorom, 2013).

The level of value relevance of accounting information for the sample is operationalised using price regression that has commonly been used in value relevance of accounting information ( see, (Barth et al., 2001; Gordon, 2001; Mechelli and Cimini, 2014)) studies and empirically tested. Share price is being used in the survey as dependent variable while disaggregated assets (Current assets and fixed assets), and liabilities (Current liabilities and non-current liabilities) as independent variables. Panel data regression was employed throughout the regression analysis. The data is divided into two periods as pre-and post-adoption of IFRS. Pre-adoption period commenced from 2009 to 2011 (three Years), and post-adoption is 2012 to 2013(two years).

In Nigeria, all listed firms are mandated to report their financial statement by the IFRS effective 2012. However, before the period of 2012 companies in Nigeria were expected to report based on the Nigerian domestic accounting reporting (SAS). Despite the importance of the value relevance of disaggregated assets and liabilities to investors little or no studies were conducted in emerging markets particularly in Nigeria. One of the important study conducted on aggregated assets and liabilities was from Kadri et al. (2010) from Malaysia. Therefore, this study is important for the investors, standard setters and policy makers in Nigeria to understand the relevance of disaggregated assets and liabilities.

\section{Literature Review}

Value relevance has been defined as an association between accounting amounts and security values (Barth \& Beaver 2000). The ability for accounting reporting to summarise and capture accounting information affecting share information has been examined in testing the statistical relationship between accounting numbers and market values and mapping from financial statements to "intrinsic" values (Aboody et al., 2002; Hellström, 2006; Vijitha and Nimalathasan, 2014). Similarly, value relevance of financial information can be predictive and statistically measured through the relationship between stock market values from the information reported on the financial statement (Barth et al., 2001) with the ability to the information provided in the annual reports to summarise and capture firm value (Beisland, 2009; Kargin, 2013b). As the ability to account information provided by a financial statement to report and summarise firm value (Păşcan, 2015).

Several scholars have studied the value relevance of accounting information in different perspectives. Beisland (2009) reported that majority of value relevance researches are related to market efficiency because they can provide the relationship between accounting measures and stock prices. Holthausen and Watts (2001) examined whether the relations between accounting numbers and stock prices are value relevant in explaining market value. Ebaid (2012) studied the influence of accounting-based methods on market returns and prices and their predictive values to be referred to as the value relevance of accounting reporting. Brien (2005) emphasised that relevance and reliability be the capacity of accounting numbers to summarise and capture accounting information that has a significant effect on stock prices. Kommunuri (2008) provided that relevance and reliability of accounting information be two key features of accounting information. 
Barth (1994) measured value relevance of banks' investment securities using fair value and historical cost for both assets and related earnings. The study provides evidence on the two methods of relative and incremental explanatory power with relative measurements error. Barth (1994) documented that fair value measurement estimates from investment securities have more significant explanatory power over historical costs. The results of fair value of gains and losses from securities investment have no significant incremental power; historical cost provides significant incremental explanatory power over fair value. In contrast, Ahmed and Carolyn (1995) document different results compared to Barth (1994) with the controlling effects of other net assets. They found that both Realised and unrealised gains and losses to provide a significant positive effect in regular periods of bank returns, although realised security gains and losses have lower significant effect in a period of weak earnings and capital.

Mozes (2002) examined fair value disclosures as required by the Statement of Financial Accounting Standards (SFAS) 119, derivatives disclosure of fair value of the financial instrument to be value relevant. The study adopted residual valuation model to investigate the association between two variables to measure the fair value of book value and security prices of financial instruments. Also, Mozes found that firms with a greater return on investment on capital have a relative cost of capital growth; the estimated relationship will improve and becomes negative in fair value of book value.

Barth and Clinch (1998) reported that intangible assets are value relevant regardless of re-evaluation period, and non-financial firms' investment is value relevant other than the current year. Baboukardos and Rimmel (2014) concluded that relevant accounting numbers on purchased goodwill generate relevant accounting numbers on companies that have a high disclosure only under IFRS.

\subsection{Studies Conducted Related to Value Relevance and IFRS}

Studies on value relevance research provide contradictive results as a result of factors in which the study is carried out (Mironiuc et al., 2015). However, several studies were conducted on the value relevance in a different environment and context because of the growing number of accounting information demand.

Agostino et al. (2011) investigated European banks the relevance of association between stock market, book value and earnings for the periods before and after the adoption of IFRSamong European banks. The findings provided that, book value and earnings to be more informative after the post-adoption of IFRS. Also, Palea (2014) examined the value relevance of different financial statements in Italian firms under GAAP and IFRS. The report of their study showed that separate financial reports were value relevant because they both provided useful information to the capital market. Contrary to expectations, the findings indicated that reporting under IFRS to have less incremental information content than Italian GAAP. Using Bursa Malaysia, Kwong (2010) examined pre- and post-adoption of IFRS for the period of 1993 to 2007 using the balance sheet and income statements. Overall, IFRS was more value relevant than GAAP for investors' decision-making and book value, and earnings were significantly valued relevant in the old regime which is consistent with Kadri et al. (2009). In contrast, Kwong (2010) found that earnings had greater value relevance under IFRS than book value under Bursa Malaysia.

Prather-Kinsey (2006) measured two different capital markets using earnings announcement (Johannesburg Stock Exchange (JSE), South Africa \& Bolsa Mexicana de Valores (BMV) Stock, Mexico), testing the association between book value and earnings with firm market value. He reports that book values were value relevant in both markets, with the significant positive association between earnings or equity values and market value in the published financial statements in the two markets. There was also immediate significant increase in earnings announcements in the JSE.

Khanagha (2011) adopted two periods of accounting information using samples of the ADX under pre- and post-IFRS adoption to determine the value relevance of accounting variables. Two empirical (models) approaches were employed for the study portfolio: return approach and regression-variations approach. The assumption of the adoption of the two methods is that they will offer different viewpoints on the issue of value relevance of accounting information in the ADX. The study adopted 17 entities that are listed on the ADX for the samples of the survey periods of 2001-2008 with 136 firm-year observations for eight years using regression-variation approach; while the portfolio approach employed 119 firm-year observations for seven years. The results obtained from the two methods provide evidence that the portfolio approach has more information content under the ADX capital market before adoption. Similarly, a decline in value relevance of accounting measures after the adoption of IFRS was noticed when the two approaches were combined. This combined results showed that there was no improvement on value relevance after the enactment of the IFRS. This concurs with Francis and Schipper (1999) that portfolio approach measures relevance more than the explained variation test.

Several studies on the value relevance of accounting information were conducted in Nigeria using different perspectives. Mohammed and Lode (2015) analysed the value relevance of assets and liabilities on explaining the market value in the Nigerian stock market from 2009 to 2013(five years) for the pre-and post-adoption of IFRS. The report of the study provides evidence of an increase in value relevance of accounting information after the adoption of IFRS. Similarly, Omokhudu and Ibadin (2015) study was related to earnings, cash flows and dividend from 1994 to 2013(ten years). The findings show that earnings, cash flows, and dividend were significantly associated with stock prices, but found book value not to be statistically significant. Furthermore, the study of Uthman and Abdul-Baki (2014) related to the extent of finance theory on the timing of information among Nigerian firms. The study measured IFRS disclosure and fair value valuation of economic events. The study findings revealed that there is a significant relationship between IFRS and finance measurement of information. They conclude that IFRS enhanced value relevance of accounting information in Nigeria.

This present study differs with other studies in Nigeria in the sense that, they based their research findings on the book value, earnings, and cash flows. Consequently, the results of the survey were concluded base on the adjusted $\mathrm{R}^{2}$, consistent with (Ball et al., 2000; Graham et al., 2000). Even though Mohammed and Lode (2015) 
conducted a study on assets and liabilities in Nigeria, and measured value relevance based on the adjusted $\mathrm{R}^{2}$. This study uses selected assets and liabilities that uses adjusted $\mathrm{R}^{2}$ for the value relevance with an additional test from ${ }^{1}$ Cramer (1987) statistics to determine the explanatory power and significant statistics of the adjusted $\mathrm{R}^{2}$.

\section{Data and Methodology \\ 3.1. Sample Description}

To determine the value relevance of accounting information, the study generates data derived from 2009 to 2013 from Nigerian listed firms. The periods were petitioned into two as pre-IFRS(2009-2011) and post-IFRS adoption (2012-2013) to observe whether there is an increase in value relevance of accounting information. Two sources for data collection were used, first for non-financial firms data was collected from Thomson Reuters DataStream and Secondly, financial firms data was collected from Bankscope data stream. All companies that have been reporting IFRS in Nigeria and listed in the Nigerian Stock Market were hand picked for the study. Table 1 has the number of samples for the for the study. The first column (column 1) presents cross-sectional years employed for the survey, with 126 samples. The second column (column 2) is the number of observation of 630, 378 and 273-year observations for pooled samples, pre-and post-adoption respectively. The third column (column 3 ) is the samples for the non-financial firms present 70 companies for pooled, pre-and post-adoption. The fourth column(column 4) is the 350 observation for pooled data and 210 and 140 for the pre-and post-adoption of IFRS respectively. The fifth column(column 5) is the sample of financial firms in the study that 56 for pooled and preand post-adoption of IFRS. Last is six column(column 6) that has an observation of 280, 16 and 112 for the pooled, pre-and post-adoption of IFRS.

Table-1. Number of firms 2009-2013

\begin{tabular}{|c|c|c|c|c|c|c|}
\hline Year & Column1 Samples & $\begin{array}{l}\text { Column2 } \\
\text { Observ }\end{array}$ & $\begin{array}{l}\text { Column } 3 \\
\text { Non-financials }\end{array}$ & $\begin{array}{l}\text { Column } 4 \\
\text { Observ }\end{array}$ & $\begin{array}{l}\text { Column } 5 \\
\text { Financials } \\
\end{array}$ & $\begin{array}{l}\text { Column } 6 \\
\text { Observation }\end{array}$ \\
\hline \multicolumn{7}{|c|}{ Pooled Samples 2009-2013 } \\
\hline $2009-2013$ & 126 & 630 & 70 & 350 & 56 & 280 \\
\hline \multicolumn{7}{|c|}{ Pre-IFRS 2009-2011 } \\
\hline 2009 & 126 & 378 & 70 & 210 & 56 & 168 \\
\hline 2010 & 126 & 378 & - & - & - & - \\
\hline 2011 & 126 & 378 & - & - & - & - \\
\hline \multicolumn{7}{|c|}{ Post-IFRS 2012-2013 } \\
\hline 2012 & 126 & 252 & 70 & 140 & 56 & 112 \\
\hline 2013 & 126 & 252 & - & - & - & - \\
\hline
\end{tabular}

\subsection{Methodology and Models}

Most often value relevance models are measured by regressing stock prices and accounting disclosures (Liu et al., 2012). According to Lang et al. (2006) accounting data are expected to be more useful if they show a higher association with market value. The stock price is collected three (3) months after the end of fiscal year as the required by the NSE for announcement date. A test for value relevance for the two the period is conducted with the $\mathrm{R}^{2}$ as in the equation 1A using Ohlson (1995) model. Price model is reported to have more advantages over return models because the model anticipate accounting earnings components and at the beginning of stock price all anticipated are incorporated (Chen et al., 2001). In contrast, Kothari and Zimmerman (1995) stated that price model produces unbiased coefficients in earnings because prices reveal total earnings information effect. The significant test to compare the differences between $\mathrm{R}^{2}$ of the two periods was done with ${ }^{2}$ Cramer (1987)

Then the test of value relevance is conducted with the R2 from Eq. (1) Based on Ohlson (1995) framework. R2 of two consecutive periods are then compared with Cramer (1987).

$\begin{array}{ll}P_{j t}=a_{0}+\beta_{1} C A_{j t}+\beta_{2} F A_{j t}+\beta_{3} C L_{j t}+\beta_{4} N C L_{j t}+\beta_{5} A U D_{j t}+\mu_{j t} & 1 \mathrm{~A} \text { and } 1 \mathrm{~B} \\ P_{j t}=a_{0}+\beta_{1} C A_{j t}+\beta_{5} A U D_{j t}+\mu_{j t} & 1 \mathrm{C} \\ P_{j t}=a_{0}+\beta_{3} F A_{j t}+\beta_{5} A U D_{j t}+\mu_{j t} & 1 \mathrm{D} \\ P_{j t}=a_{0}+\beta_{4} C L_{j t}+\beta_{5} A U D_{j t}+\mu_{j t} & 1 \mathrm{H} \\ P_{j t}=a_{0}+\beta_{5} N C L_{j t}+\beta_{5} A U D_{j t}+\mu_{j t} & 1 \mathrm{I}\end{array}$

Where $P_{j i}=$ value of the firm.

$C A_{j t}=$ Current Assets for firm $\mathrm{i}$ at the end of year $\mathrm{t}$

$F A_{j t}=$ Fixed Assets for firm $\mathrm{i}$ at the end of year $\mathrm{t}$

$C L_{j t}=$ Current Liabilities for firm i at the end of year $\mathrm{t}$

$N C L_{j t}=$ Non-Current Liabilities for firm $\mathrm{i}$ at the end of year $\mathrm{t}$

$A U D_{j t}=$ Audit as dummy variable " 1 " for firms that uses audit '4" and '0' otherwise. All variables are deflated by the total number of outstanding shares

${ }^{1}$ To determine the statistical significance of adjusted $\mathrm{R}^{2}$

${ }^{2}$ Statistical comparisons are based on the expectation and variance of R2 as derived in Cramer (1987). Z-statistics as follows:

$$
Z=\frac{R_{1}^{2}+R_{2}^{2}}{\sqrt{\delta^{2}\left(R_{1}^{2}+\delta^{2}\left(R_{2}^{2}\right)\right.}}
$$




\section{Discussion of Results}

Table 2 provides the result of yearly cross-sectional regression data of Model 1, of share price on current assets, fixed assets, current liabilities and non-current liabilities. Ordinary Least Square (OLS) estimation that has commonly been used in value relevance studies is employed to calculate the coefficients estimates. The adjusted $\mathrm{R}^{2}$ in Table 2 range from $16.19 \%$ in 2011 to $22.48 \%$ in 2012 with an average mean of $21 \%$. The coefficients of CA, FA, and AUD are positive and significant in each year with a $p<0.05 \%$ expect in the year 2010 with CA significant level of $\mathrm{p}<0.10 \%$. Furthermore, variables CL and NCL have a significant negative level as expected with the $\mathrm{p}<0.05 \%$. The diagnostic test was conducted in the state include, (i) Multicollinearity is appraised by Variance Inflation Factors(VIF). The VIF provide no evidence of multicollinearity issue in the model, and (ii) White (1980) test on heteroscedasticity is found to be significant in some period and not significant in other periods. However, that has been taken care by robust standard error.

\begin{tabular}{|c|c|c|c|c|c|c|c|}
\hline \multicolumn{3}{|l|}{ Model1 } & \multirow{2}{*}{ 1 A } & \multirow{2}{*}{$\frac{\alpha_{0}+\beta_{1} C A_{i t}+}{\beta_{3}}$} & \multirow{3}{*}{$\frac{\beta_{2} \mathbf{F} A_{i t}+\beta_{3} C}{\beta_{3}}$} & \multicolumn{2}{|c|}{ 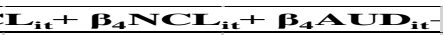 } \\
\hline \multirow{2}{*}{\multicolumn{7}{|c|}{\begin{tabular}{l|l|l} 
& $\beta_{3}$ & $B_{3}$ \\
2009 &
\end{tabular}}} & \\
\hline & & & & & & & \\
\hline coeff & 0.3026 & 0.0802 & 0.0047 & -0.0021 & -0.2345 & 0.6155 & 0.2097 \\
\hline t-value & 1.13 & 3.28 & 10.69 & -2.65 & -3.17 & 1.98 & \\
\hline p-value & 0.261 & 0.001 & 0.000 & 0.009 & 0.002 & 0.050 & \\
\hline vif & & 1.15 & 1.01 & 1.02 & 1.02 & 1.11 & \\
\hline white & & 0.0204 & 0.3652 & 0.0002 & 0.2121 & 0.2131 & \\
\hline & \multicolumn{7}{|c|}{2010} \\
\hline Coent & 0.4733 & 0.0756 & 0.0013 & -0.0008 & -0.2221 & 0.6492 & 0.2294 \\
\hline t-value & 1.66 & 3.99 & 4.77 & -2.65 & -3.87 & 1.98 & \\
\hline p-value & 0.100 & 0.000 & 0.000 & 0.009 & O.OOO & 0.050 & \\
\hline vif & & 1.01 & 1 & 1.03 & 1.02 & 1.03 & \\
\hline white & & O.000 & 0.023 & 0.002 & 0.453 & O.OOO & \\
\hline \\
\hline coefr & 0.6417 & 0.0465 & 0.0025 & -0.0003 & -0.1367 & 0.5994 & 0.1619 \\
\hline t-value & 2.08 & 1.83 & 4.23 & -0.97 & -1.77 & 1.74 & \\
\hline p-value & 0.039 & 0.070 & 0.000 & 0.335 & 0.079 & 0.085 & \\
\hline vif & & 1.110 & 1.020 & 1.070 & 1.020 & 1.210 & \\
\hline white & & 0.000 & 0.213 & 0.654 & 0.324 & 0.654 & \\
\hline \multicolumn{8}{|c|}{2012} \\
\hline coeff & 0.6969 & 0.0591 & 0.0055 & -0.0025 & -0.1635 & 0.5354 & 0.2248 \\
\hline t-value & 2.29 & 3.59 & 7.4 & -3.83 & -3.29 & 1.58 & \\
\hline p-value & 0.024 & O.oOO & O.OOO & O.OOO & O.OO1 & 0.118 & \\
\hline vif & & 1.200 & 1.300 & 1.020 & 1.020 & 1.010 & \\
\hline white & & 0.054 & 0.000 & 0.235 & 0.243 & 0.068 & \\
\hline \multicolumn{8}{|c|}{2013} \\
\hline coerf & 0.738986 & 0.0646 & 0.0046 & -0.0024 & -0.1791 & 0.7109 & 0.2236 \\
\hline t-value & 2.6 & 2.54 & 6.11 & -2.84 & -2.34 & 2.23 & \\
\hline p-value & 0.010 & 0.012 & O.DOO & 0.005 & 0.021 & 0.028 & \\
\hline vif & & 1.010 & 1.000 & 1.020 & 1.020 & 1.220 & \\
\hline white & & 0.355 & 0.037 & 0.088 & 0.765 & 0.254 & \\
\hline
\end{tabular}

Q $\mathrm{CL}=$ current liabilities for firm $i$ at the end of the year $\mathrm{t}$. $\mathrm{NCL}=$ non-current liabilities for firm $i$ at the end of the year $t$. AUD $=\mathrm{AUD}=\mathrm{Auditors}$ as dummy variable " 1 " for "Big 4" auditors and "0" otherwise. All variables are deflated by the total number of outstanding shares. $\beta=$ Coefficient of the explanatory variables. white's heteroscedasticity- consistent variances and standard error significant level of $\mathrm{p}<1 \%, 5 \%, \& 10 \%$. $\mathrm{R}^{2}=\mathrm{Adjusted} \mathrm{R}^{2}$ within the panel regression. All p-values are estimated based on the White (1980) corrected error for heteroscedasticity

Table 3 was divided into two Panels (Panel A and Panel B). Panel A presents pooled data for all the variables and data for the pre-and post-adoption of IFRS. The panel also has the pooled data for CA and FA and also pre-and post-adoption of IFRS. Panel B provides the regression analysis of CL and NLC pooled data and pre-and postadoption of IFRS.

Panel A data is the regression analysis of pooled data that utilises all the observation of 630 from 126 firms for the before and after the adoption of all variables. The panel also provides observations of 378 for the data before the adoption and 252 after the adoption of IFRS. The value relevance of accounting information has shown to improve in the periods after adoption for the pooled data and CA, FA, (total adjusted R2 before $=18.77 \%$ and after $=22.11 \%$ for pooled data, $\mathrm{CA}$ before $=5.48 \%$ and after $=7.96 \%$, FA before $=4.83 \%$ and after $=6.03 \%$ )

In the Panel B presents 630 observations from 126 firms for the pooled data of NCL and CL. The panel also provides observations of 378 for the data before the adoption and 252 after the adoption of IFRS. However, the variable NCL provides a greater value relevance of accounting information after the adoption (before $=4.64 \%$ and after $=4.74 \%$ ). However, CL presents a decline in the value relevance of accounting information (adjusted $\mathrm{R}^{2}$ before $=3.56 \%$ and after $=3.45 \%$ ).

The study compares the adjusted $\mathrm{R}^{2}$ of 2009 and 2011 with that of 2012 and 2013 to examine whether there is more value relevance of accounting information after the adoption. Using ${ }^{3}$ Cramer's (1987) Z statistic test, there is no evidence of significant statistical differences between pre-and post-adoption (Panel A and $\mathrm{B}$, the $\mathrm{Z}$ value preand post-adoption, pooled data $=0.2823$, individual variables $\mathrm{CA}=0.04902, \mathrm{FA}=0.04901, \mathrm{CL}=0.048803$, and $\mathrm{NCL}=0.48803$ ). Even though the results of adjusted $\mathrm{R}^{2}$ provide evidence of increase between pre-and postadoption of IFRS but no evidence the $\mathrm{R}^{2}$ between the two periods is statistically different.

The last columns in the Panel B, last three columns in the Panel B show the incremental explanatory power of value relevance of each of the variables (CA, FA, Cl, NCL) together with the common explanatory power. The variable CA total variant in stock prices explained and increase from $13.29 \%$ at the period before to $14.5 \%$ in the period after and (FA before $=13.94 \%$ and, after $=16.03 \%$, CL before $15.32 \%$ and after $=18.66 \%$, NCL before $=14.13 \%$ and after $=17.37 \%$ ). The results presented in the column suggest an increase in value relevance, but the Cramer's Z provides no statistical significance difference between the $\mathrm{R}^{2}$.

The findings of the study need to be interpreted with care; this is because firms that did not provide data from 2009 to 2013 are excluded from the survey. The study also uses three years before and two years after the adoptions as the number of samples are not equal, with a deficiency of 1 year after the adoption. Furthermore, unlike Graham et al. (2000) their study measured adjusted R2 for only one year within four quarters for 1997 and

\footnotetext{
${ }^{3}$ The $\mathrm{Z}$ values in the model did not provide and significant value. $\mathrm{P}$ is not significant in all the variables
} 
1998. This study will conclude that Nigerian, adoption of IFRS had a marginal improvement in value relevance of accounting information from 2009 to 2013 . Another evidence, Liu et al. (2012) reported that results from adopting IFRS often provides support for the differences on the relevance of accounting information, so also, when a new standard is applied to the same accounting regulations.

Table-3. Stock Price Models Panel A: Pooled regression results of selected assets and liabilities

\begin{tabular}{|c|c|c|c|c|c|c|c|c|c|c|c|c|c|}
\hline \multirow{2}{*}{ Price $^{1}$} & \multicolumn{5}{|c|}{$1 \mathrm{~B}: \alpha 1+\beta 1 \mathrm{CA}_{\mathrm{it}}+\beta 2 \mathrm{FA}_{\mathrm{it}}+\beta 3 \mathrm{CL}_{\mathrm{it}}+\beta 4 \mathrm{NCL}_{\mathrm{it}}+\beta 5 \mathrm{AUD}_{\mathrm{it}}$} & \multicolumn{4}{|c|}{$1 \mathrm{C}: \beta 1 C A_{i t}+\beta 5 A_{U D D}$} & \multicolumn{4}{|c|}{ 1D: $\beta_{2} \mathrm{FA}_{\mathrm{it}}+\beta 5 \mathrm{AUD}$ it } \\
\hline & $\alpha 1$ & & $\beta 2$ & $\beta 3$ & $\beta 4$ & $\beta 5$ & $\mathbf{R} 2$ & $\beta 1$ & B5 & $\mathbf{R} 2$ & $\beta 2$ & $\beta 5$ & $\mathbf{R} 2$ \\
\hline \multicolumn{14}{|c|}{ POOLED DATA 2009-2013 } \\
\hline Coef & 0.5823 & 0.0596 & 0.0026 & -0.0008 & -0.1746 & 0.6394 & 0.1903 & 0.26704 & 0.831783 & 0.0545 & 0.0032 & 0.8319 & 0.0484 \\
\hline tvalue & 4.54 & 5.51 & 3.75 & -2.83 & -5.33 & 4.39 & & 3.61 & 5.44 & & 4.24 & 5.45 & \\
\hline p-value & 0.000 & 0.000 & 0.000 & 0.005 & 0.000 & 0.000 & & 0.000 & 0.000 & & 0.000 & 0.000 & \\
\hline \multicolumn{14}{|c|}{ PRE-ADOPTION 2009-2011 } \\
\hline Coef & 0.4775 & 0.0608 & 0.0022 & -0.0006 & -0.1789 & 0.6407 & 0.1877 & 0.0022 & 0.8385 & 0.0548 & 0.0028 & 0.8429 & 0.0483 \\
\hline tvalue & 2.9 & 3.65 & 3.95 & -2.12 & -3.54 & 3.4 & & 4.84 & 4.19 & & 4.58 & 4.24 & \\
\hline p-value & 0.004 & 0.000 & 0.000 & 0.034 & 0.000 & 0.001 & & 0.000 & 0.000 & & 0.000 & 0.000 & \\
\hline \multicolumn{14}{|c|}{ POST-ADOPTION 2012-2013 } \\
\hline Coef & 0.7199 & 0.061 & 0.0051 & -0.0025 & -0.1691 & 0.6232 & 0.2211 & 0.0087 & 0.8027 & 0.0796 & 0.0053 & 0.8671 & 0.0603 \\
\hline tvalue & 3.51 & 4.41 & 10.21 & -4.64 & -4.05 & 2.71 & & 3.83 & 3.41 & & 5.28 & 2.61 & \\
\hline p-value & 0.001 & 0.000 & 0.000 & 0.000 & 0.000 & 0.007 & & 0.000 & 0.001 & & 0.000 & 0.010 & \\
\hline \multicolumn{2}{|c|}{ Cram Z Statistic } & & & & & & 0.2823 & & & 0.49202 & & & 0.49601 \\
\hline
\end{tabular}

***Significant level 1\%**significant level 5\%* significant level 10\%

1 price regression: $\mathrm{SP}=\alpha 1+\beta 1 \mathrm{CA}_{\mathrm{it}}+\beta 2 \mathrm{FA}_{\mathrm{it}}+\beta 3 \mathrm{CL}_{\mathrm{it}}+\beta 4 \mathrm{NCL}_{\mathrm{it}}+\beta 5 \mathrm{AUD}_{\mathrm{it}}+\mu_{\mathrm{it}} \mathrm{SP}=\beta 1 \mathrm{CA}_{\mathrm{it}}+\beta 5 \mathrm{AUD}_{\mathrm{it}}+\mu_{\mathrm{it}} \mathrm{SP}=\beta 2 \mathrm{FA}_{\mathrm{it}}+{ }_{\mathrm{t}}+\beta \mathrm{AUD}_{\mathrm{it}}+\mu_{\mathrm{it}}$

Variable definitions for Table 15: $\mathrm{SP}=$ Share price of firm three months after the year end t. $\mathrm{CA}=\mathrm{Current}$ assets per share of firm $\mathrm{i}$ at the end of fiscal year $\mathrm{t}$. $F A=F i x e d$ assets for firm $i$ at the end of fiscal year $t$. $C L=C$ urrent liabilities per share of firm $i$ at the end of fiscal year $t$. NCL=Non-current assets for firm $i$ at the end of fiscal year t. AUD = Auditors as dummy variable " 1 " for "Big 4" auditors and " 0 " otherwise. $\beta=$ Coefficient of the explanatory variables. $\mathrm{R}^{2}=$ Adjusted $\mathrm{R}^{2}$ within the panel regression. Cramer (1987) is for the statistical difference in adjusted $\mathrm{R}^{2}$ between Pre-and Post-adoption of IFRS from table lists p-values. All p-values are estimated based on the White (1980) corrected error for heteroscedasticity

Table-3. continued

B: Pooled regression results of selected assets and liabilities

\begin{tabular}{|c|c|c|c|c|c|c|c|c|c|c|c|}
\hline \multirow[t]{2}{*}{ Price $^{1}$} & \multicolumn{2}{|c|}{ 1H: $\beta 3 C L_{i t}+\beta 5 A U D_{i t}$} & \multicolumn{4}{|c|}{ 1I: $\beta 3 N C L_{i t}+\beta 5 A U D_{i t}$} & \multicolumn{3}{|c|}{ Incremental } & \multirow[b]{2}{*}{$\operatorname{NCL} R^{2}$} & \multirow[b]{2}{*}{ Comm } \\
\hline & 及 3 & $\beta 5$ & $\mathbf{R}^{2}$ & B 4 & $\beta 5$ & $\mathbf{R}^{2}$ & $\mathbf{C A} \mathbf{R}^{2}$ & FA R $\mathbf{R}^{2}$ & $\mathbf{C L} \mathbf{R}^{2}$ & & \\
\hline \multicolumn{12}{|c|}{ POOLED DATA } \\
\hline coef & -0.0003 & 0.8481 & 0.0346 & 0.0057 & 0.844 & 0.0433 & 0.1358 & 0.1419 & 0.1557 & 0.0147 & 0.5804 \\
\hline tvalue & 3.58 & 5.52 & & 5.57 & 5.5 & & & & & & \\
\hline p-value & 0.000 & 0.000 & & 0.000 & 0.000 & & & & & & \\
\hline \multicolumn{12}{|c|}{ PRE-ADOPTION 2009-2011 } \\
\hline coef & -0.0033 & 0.8543 & 0.0356 & $\mathbf{0 . 0 3 5 6}$ & 0.0052 & 0.0464 & 0.1329 & 0.1394 & $\mathbf{0 . 1 5 3 2}$ & 0.1413 & 0.5668 \\
\hline tvalue & -5.87 & 4.26 & & 6.94 & 4.24 & & & & & & \\
\hline p-value & 0.000 & 0.000 & & 0.000 & 0.000 & & & & & & \\
\hline \multicolumn{12}{|c|}{ POST_ADOPTION 2012-2013 } \\
\hline coef & -0.0035 & 0.8378 & 0.0345 & 0.0147 & 0.833 & 0.0474 & 0.1415 & 0.1603 & 0.1866 & 0.1737 & 0.6621 \\
\hline tvalue & -1.57 & 3.51 & & 5.06 & 3.51 & & & & & & \\
\hline p-value & 0.117 & 0.001 & & 0.000 & 0.000 & & & & & & \\
\hline \multicolumn{3}{|c|}{ Cramer-test(p-value) } & 0.48803 & & & 0.48803 & & & & & \\
\hline
\end{tabular}

***Significant level $1 \% * *$ significant level $5 \% *$ significant level $10 \%$

1 price regression: $\mathrm{SP}=\alpha_{1}+\beta_{1} \mathrm{CA}_{\mathrm{it}}+\beta_{2} \mathrm{FA}_{\mathrm{it}}+\beta_{3} \mathrm{CL}_{\mathrm{it}}+\beta_{4} \mathrm{NCL}_{\text {it }}+\beta_{5} \mathrm{AUD}_{\mathrm{it}}+\mu_{\mathrm{it}} \mathrm{SP}=\beta_{1} \mathrm{CL}_{\text {it }}+\beta 5 \mathrm{AUD} \mathrm{D}_{\mathrm{it}}+\mu_{\mathrm{it}} \mathrm{SP}=\beta_{2} \mathrm{NCL}_{\mathrm{it}}+\beta_{\mathrm{t}}+\mathrm{AUD}_{\mathrm{it}}+\mu_{\mathrm{it}}$

Variable definitions for Table 15: SP= Share price of firm three months after the year end t. CA=Current assets per share of firm i at the end of fiscal year t. FA=Fixed assets for firm $i$ at the end of fiscal year t. $C L=C$ Current liabilities per share of firm $i$ at the end of fiscal year $t$. NCL=Non-current assets for firm $i$ at the end of fiscal year t. AUD = Auditors as dummy variable " 1 " for "Big 4" auditors and " 0 " otherwise. $\beta=$ Coefficient of the explanatory variables $\mathrm{R}^{2}=$ Adjusted $\mathrm{R}^{2}$ within the panel regression. Cramer (1987) is for the statistical difference in adjusted $\mathrm{R}^{2}$ between Pre-and Post-adoption of IFRS from table lists p-values. All p-values are estimated based on the White (1980) corrected error for heteroscedasticity

\section{Robust Test}

To find whether the value relevance of accounting information is as a result of non-financial or financial firms. We separate the firms into two for non-financial and financials in Table 4 and Table 5.

\subsection{Regression for Non-Financial Firms}

The result in Table 4 presents regression result of non-financial companies for the selected assets and liabilities. The coefficient of estimates for the pooled data for CA and FA are positively significant, and CL and NCL are negatively significant, all the variables CA, FA, CL and NCL have a significant level of associations $\mathrm{p}<0.001 \%$ with the stock price for the pooled data. The results of before and after the adoption present similar results expect NCL that does not provide any significant level of association with stock prices before and after the adoption of IFRS. The results from the regression provide evidence of increase value relevance of accounting information from the increased adjusted $\mathrm{R}^{2}$ provided in the table (Adjusted $\mathrm{R}^{2}$ before $=21.49 \%$ and after $=24.19 \%$ ). Supporting the pooled data of having higher adjusted $\mathrm{R}^{2}$ after the adoption of IFRS. The Cramer $\mathrm{Z}$ statistics shows no statistically significant difference between the two periods equally.

\subsection{Regression of Financial Firms}

The result in Table 5 presents regression result of non-financial firms for the selected assets and liabilities. The coefficient of estimates for the pooled data for CA and FA are positively significant, and 
CL and NCL are negatively significant, all the variables CA, FA, CL and NCL have a significant level of $\mathrm{p}<0.001 \%$ with the stock price for the pooled data.

Table-4. Price Regression Model 1 Non-Financial Selected Assets and Liabilities

\begin{tabular}{|c|c|c|c|c|c|c|c|}
\hline \multirow[t]{2}{*}{ Price $^{1}$} & \multicolumn{7}{|c|}{$1 \mathrm{~F}: \alpha_{0}+\beta_{1} \mathrm{CA}_{\mathrm{it}}+\beta_{2} \mathrm{FA}_{\mathrm{it}}+\beta_{3} \mathrm{CL}_{\mathrm{it}}+\beta_{4} \mathrm{NCL}_{\mathrm{it}}+\beta_{5} \mathrm{AUD}_{\mathrm{it}}$} \\
\hline & $\alpha_{1}$ & $\beta_{1}$ & $\boldsymbol{\beta}_{2}$ & $\beta_{3}$ & $\boldsymbol{\beta}_{4}$ & $\beta_{5}$ & $\mathbf{R}^{2}$ \\
\hline \multicolumn{8}{|c|}{ POOLED DATA 2009-2013 } \\
\hline coef & 1.2631 & 0.0569 & 0.0020 & -0.0010 & -0.1669 & 0.3206 & 0.2070 \\
\hline tvalue & 4.98 & 7.08 & 3.54 & -3.45 & -6.85 & 1.2 & \\
\hline p-value & 0.000 & 0.000 & 0.000 & 0.001 & 0.000 & 0.230 & \\
\hline \multicolumn{8}{|c|}{ PRE-ADOPTION 2009-2011 } \\
\hline coef & 0.0651 & 0.0015 & 0.0009 & -0.1921 & -0.3986 & 1.0620 & 0.2149 \\
\hline tvalue & 6.23 & 3.52 & 3.84 & -6.07 & 1.13 & 3.14 & \\
\hline p-value & 0.000 & 0.001 & 0.000 & 0.000 & 0.261 & 0.002 & \\
\hline \multicolumn{8}{|c|}{ POST-ADOPTION-2012-2013 } \\
\hline coef & 0.0516 & 0.0040 & 0.0026 & -0.1407 & -0.1789 & 1.5302 & 0.2419 \\
\hline tvalue & 4.33 & 8.01 & 5.85 & -3.93 & 0.45 & 4.09 & \\
\hline p-value & 0.000 & 0.000 & 0.000 & 0.000 & 0.654 & 0.000 & \\
\hline
\end{tabular}

Cramer-test(p-value) 0.4880

***Significant level 1\%**significant level $5 \% *$ significant level $10 \%$

1 price regression: $\mathrm{SP}=\alpha_{0}+\beta_{1} \mathrm{CA}_{\mathrm{it}}+\beta_{2} \mathrm{FA}_{\mathrm{it}}+\beta_{3} \mathrm{CL}_{\mathrm{it}}+\beta_{4} \mathrm{NCL}_{\mathrm{it}}+\beta_{5} \mathrm{AUD}_{\mathrm{it}}+\mu_{\mathrm{it}}$

Variable definitions for Table 3: SP= Share price of firm three months after the year end t. $\mathrm{CA}=\mathrm{Current}$ assets per share of firm $\mathrm{i}$ at the end of fiscal year $\mathrm{t}$. FA=Fixed assets for firm $i$ at the end of fiscal year t. $C L=C$ urrent liabilities per share of firm $i$ at the end of fiscal year $t$. NCL=Non-current assets for firm $i$ at the end of fiscal year t. AUD = Auditors as dummy variable " 1 " for "Big 4" auditors and "0" otherwise. $\beta=$ Coefficient of the explanatory variables. $\mathrm{R}^{2}=$ Adjusted $\mathrm{R}^{2}$ within the panel regression. Cramer (1987) is for the statistical difference in adjusted $\mathrm{R}^{2}$ between Pre-and Post-adoption of IFRS from table lists p-values. All p-values are estimated based on the White (1980) corrected error for heteroscedasticity

All variables before the adoption of IFRS present similar results expect AUD with $\mathrm{p}<0.01 \%$ significant level. After the adoption of IFRS FA and NCL do not provide any significant level of association. The results from the regression provide evidence of increased value relevance of accounting information from the lower adjusted $\mathrm{R}^{2}$ in the before IFRS adoption (Adjusted $\mathrm{R}^{2}$ before $=23.80 \%$ and after=24.89\%). The Cramer $\mathrm{Z}$ statistics shows no statistically significant difference between the two periods. This could be attributed to non-use of FA and NCL by banks for investments. Also, banking sectors invest mostly in financial assets than non-financial assets.

Table-5. Price Regression Model 1 Financial Selected Assets and Liabilities

\begin{tabular}{|c|c|c|c|c|c|c|c|}
\hline \multirow[t]{2}{*}{ Price $^{1}$} & \multicolumn{7}{|c|}{$1 \mathrm{~A}: \mathrm{SP}=\alpha_{1}+\beta_{1} \mathrm{CA}_{\mathrm{it}}+\beta_{2} \mathrm{FA}_{\mathrm{it}}+\beta_{3} \mathrm{CL}_{\mathrm{it}}+\beta_{4} \mathrm{NCL}_{\mathrm{it}}+\beta_{5} \mathrm{AUD}_{\mathrm{it}}$} \\
\hline & $\alpha_{1}$ & $\beta_{1}$ & $\boldsymbol{\beta}_{2}$ & $\beta_{3}$ & $\boldsymbol{\beta}_{4}$ & $\beta_{5}$ & $\mathbf{R}^{2}$ \\
\hline \multicolumn{8}{|c|}{ POOLED DATA 2009-2013 } \\
\hline coef & 0.0605 & 0.0495 & 0.5006 & -0.0939 & -0.1573 & 0.4200 & 0.2253 \\
\hline tvalue & 0.49 & 3.88 & 7.51 & -6.09 & -3.97 & 2.93 & \\
\hline p-value & 0.627 & 0.000 & 0.000 & 0.000 & 0.000 & 0.004 & \\
\hline \multicolumn{8}{|c|}{ PRE-ADOPTION 2009-2011 } \\
\hline coef & -0.0477 & 0.4690 & 0.0838 & -0.1519 & -0.3918 & -0.0354 & 0.2380 \\
\hline tvalue & -3.92 & 6.43 & 6.91 & -3.9 & -2.22 & -0.23 & \\
\hline p-value & 0.000 & 0.000 & 0.000 & 0.000 & 0.028 & 0.821 & \\
\hline \multicolumn{8}{|c|}{ POST-ADOPTION-2012-2013 } \\
\hline coef & 0.1502 & 0.6365 & 0.5047 & -0.4461 & -0.3994 & 0.1820 & 0.2489 \\
\hline tvalue & 1.78 & 5.18 & 1.6 & -1.75 & -1.64 & 0.88 & \\
\hline p-value & 0.078 & 0.000 & 0.114 & 0.083 & 0.105 & 0.378 & \\
\hline \multicolumn{2}{|c|}{ Cramer-test(p-value) } & & & & & & 0.45620 \\
\hline
\end{tabular}

Cramer-test(p-value)

***Significant level $1 \% * *$ significant level $5 \% *$ significant level $10 \%$

1 price regression: $\mathrm{SP}=\alpha_{0}+\beta_{1} \mathrm{CA}_{\mathrm{it}}+\beta_{2} \mathrm{FA}_{\mathrm{it}}+\beta_{3} \mathrm{CL}_{\mathrm{it}}+\beta_{4} \mathrm{NCL}_{\mathrm{it}}+\beta_{5} \mathrm{AUD}_{\mathrm{it}}+\mu_{\mathrm{it}}$

Variable definitions for Table 4: SP=Share price of firm three months after the year end t. $\mathrm{CA}=\mathrm{Current}$ assets per share of firm $\mathrm{i}$ at the end of fiscal year $\mathrm{t}$. FA=Fixed assets for firm $i$ at the end of fiscal year $t$. $C L=C u r r e n t$ liabilities per share of firm $i$ at the end of fiscal year $t$. NCL=Non-current assets for firm $i$ at the end of fiscal year t. AUD = Auditors as dummy variable " 1 " for "Big 4" auditors and "0" otherwise. $\beta=$ Coefficient of the explanatory variables. $\mathrm{R}^{2}=$ Adjusted $\mathrm{R}^{2}$ within the panel regression. Cramer (1987) is for the statistical difference in adjusted $\mathrm{R}^{2}$ between Pre-and Post-adoption of IFRS from table lists p-values. All p-values are estimated based on the White (1980) corrected error for heteroscedasticity.

\section{Conclusions}

Before 2012 Nigerian firms have been reporting financial reporting based on SAS as domestic accounting reporting. Although, banks and multinationals companies were making two reports based on SAS and IFRS because of their link with international firms. The law of the country at the period all firms should prepare their financial report based on the SAS and Company and Allied Matters Act of 1990 (CAMA, 1990) However, from 2012 the Nigerian Financial Reporting Council (FRC) of Nigeria mandated all firms listed in the Nigerian stock market to prepare their financial report based on IFRS.

The financial crisis of 2008, even though it was a global issue but Nigerian stock market was considerably heating. The failure of the market in the period has made some firms in the capital market to either close down or merge with others. As a result of the turmoil, the Central Bank Nigerian (CBN) issued a bailout to the banks in the period amounting to USD3.3 Billion in 2009.

Therefore, this study addresses whether a change in accounting reporting in Nigeria has any effect on the value relevance of accounting information. The result of the study presents an increase in value relevance of accounting information after the adoption of IFRS. The results of non-financial firms provide an increase in value relevance after the adoption of IFRS. An increase in value relevance in financial firms is also noticed in the financial firms. 
The Cramer $\mathrm{Z}$ test for statistical significant provide no significance differences between the two periods all the models. Though the result provides evidence of IFRS improvement from the $\mathrm{R}^{2}$ but provides no statistical difference of the R2 between the two periods. However, CL and financial asset present lower $\mathrm{R}^{2}$ after the adoption of IFRS with no statistical differences between the two periods. This lower $\mathrm{R}^{2}$ in the two models support critics concerns on the fair value of assets and liabilities (Liu et al., 2012). In contrast, the defenders of fair value found that confusing and unnecessary, that changing in value relevance could be as a result of change in the market conditions.

\section{References}

Aboody, D., J. Hughes and J. Liu, 2002. Measuring value relevance in a (Possibly) inefficient market. Journal of Accounting Research, 40(4): 965-986. DOI http://doi.org/10.1111/1475-679X.00078.

Agostino, M., D. Drago and D. Silipo, 2011. The value relevance of IFRS in the European banking industry. Review of Quantitative Finance and, $15(1): 21-43$.

Ahmed, A.S. and T.B. Carolyn, 1995. Stock market valuation of gains and losses on commercial banks investment securities an empirical analysis. Journal of Accounting and Ecoomies, 20(20): 207-225.

Amir, E., T. Harris and E. Venuti, 1993. A comparison of the value-relevance of US versus non-US GAAP accounting measures using form 20-F reconciliations. Journal of Accounting Research, 31(3): 230-264. DOI http://doi.org/10.2307/2491172.

Baboukardos, D. and G. Rimmel, 2014. Goodwill under IFRS: Relevance and disclosures in an unfavorable environment. Accounting Forum, 38(1): 1-17.

Ball, R. and P. Brown, 1968. An empirical evaluation of accounting income numbers. Journal of Accounting Research, 6(2): $159-178$.

Ball, R., S.P. Kothari, A. Robin, R. Ny, G. Biddle, D. Collins and R. Watts, 2000. The effect of international institutional factors on properties of accounting earnings. Journal of Accounting and Economics, 9(1): 1-51.

Barth, M.E., 1994. Value accounting: Evidence from investment securities and the market valuation of banks. Accounting Review, 69(1): 125. DOI http://doi.org/10.2307/24825.

Barth, M.E., W.H. Beaver and W.R. Landsman, 1996. Value-relevance of banks fair value disclosures under SFAS No. 107. Accounting Review, 71(4): 513-537. DOI http://doi.org/10.2307/248569.

Barth, M.E., W.H. Beaver and W.R. Landsman, 2001. The relevance of the value relevance literature for financial accounting standard setting: Another view. Journal of Accounting and Economics, 31(1): 77-104. DOI http://doi.org/10.1016/S0165-4101(01)00019-2.

Barth, M.E. and G. Clinch, 1998. Revalued financial, tangible, and intangible assets : Associations with share prices and non-market-based value estimates. Journal of Accounting Research, 36(3): 199-233. DOI http://doi.org/10.2307/2491314.

Barth, M.R., W.H. Braver, J.M. Hand and W.R. Landsman, 1999. Accruals, cash flows, and equity values. Review of Accounting Studies, 4(3): 205-229. DOI http://doi.org/10.1111/j.1468-5957.2006.01425.x.

Beisland, L.A., 2009. A review of the value relevance literature. Open Business Journal, 2(1): 7-27. DOI http://doi.org/10.2174/1874915100902010007.

Brien, J.O., 2005. Relevance and reliability of fair values: Discussion of issues raised. Fair Value Accounting for Financial Instruments : Some Implications for Bank Regulation: BIS Accounting, Risk Management and Prudential Regulation Workshop, Basel, Nov. pp: $11-12$.

CAMA, 1990. Companies and allied matters act, of Nigeria. Federal Republic of Nigeria.

Chebaane, S. and B.H. Othman, 2014. The impact of IFRS adoption on value relevance of earnings and book value of equity: The case of emerging markets in African and Asian Region. Procedia - Social and Behavioral Sciences, 145(November 2015): 70-80. DOI http://doi.org/10.1016/j.sbspro.2014.06.012.

Chen, C.J., S. Chen and X. Su, 2001. Is accounting information value-relevant in the emerging Chinese stock market? Journal of International Accounting, Auditing and Taxation, 10(1): 1-22. DOI http://doi.org/10.1016/S1061-9518(01)00033-7.

Collins, D.W., E.L. Maydew and I.S. Weiss, 1997. Changes in the value-relevance of earnings and book values over the past forty years. Journal of Accounting and Economics, 24(1): 39-67. DOI http://doi.org/10.1016/S0165-4101(97)00015-3.

Cramer, J.S., 1987. Mean and variance of R2 in small and moderate samples. Journal of Econometrics, 35(2-3): 253-266.

Ebaid, I.E., 2012. The value relevance of accounting-based performance measures in emerging economies the case of Egypt, 35(1): 69-88. DOI http://doi.org/10.1108/01409171211190814.

Economist, T., 2005. The ones that get away. Ones That Get Away, 14: 65 \& 66 .

Francis, J. and K. Schipper, 1999. Have financial statements lost their relevance? Journal of Accounting Research, 37(2): 319-352. DOI http://doi.org/10.2307/2491412.

Gordon, E.A., 2001. Accounting for changing prices: The value relevance of historical cost, price level, and replacement cost accounting in Mexico. Journal of Accounting Research, 39(1): 177-200. DOI http://doi.org/10.1111/1475-679X.00008.

Graham, R., R. King and J. Bailes, 2000. The value relevance of accounting information during a financial crisis: Thailand and the 1997 decline in the value of the baht. Journal of International Financial Management and Accounting, 11(2): 84-107. DOI http://doi.org/10.1111/1467-646X.00057.

Hellström, K., 2006. The value relevance of financial accounting information in a transition economy: The case of the Czech Republic. European Accounting Review, 15(3): 325-349. DOI http://doi.org/10.1080/09638180600916242.

Holthausen, R.W. and R.L. Watts, 2001. The relevance of the value-relevance literature for financial accounting standard setting. Journal of Accounting and Economics, 31(1-3): 3-75. DOI http://doi.org/10.1016/S0165-4101(01)00029-5.

Kadri, M.H., R.A. Aziz and M.K. Ibrahim, 2009. Value relevance of book value and earnings: Evidence from two different financial reporting regimes. Journal of Financial Reporting and Accounting, 7(1): 1-16. DOI http://doi.org/10.1108/19852510980000638.

Kadri, M.H., M.K. Ibrahim and R.A. Aziz, 2010. Value relevance of aggregated vs disaggregated book value and earnings: Evidence from Malaysian high-tech firms. Malaysian Accounting Review, 9(1): 1-17.

Kargin, S., 2013a. The impact of IFRS on the value relevance of accounting information: Evidence from Turkish firms. International Journal of Economics and Finance, 5(4): 71-80. DOI http://doi.org/10.5539/ijef.v5n4p71.

Kargin, S., 2013b. The impact of IFRS on the value relevance of accounting information: Evidence from Turkish firms. International Journal of Economics and Finance, 5(4): 71-80. DOI http://doi.org/10.5539/ijef.v5n4p71.

Khanagha, J.B., 2011. The impact of reforms on the value relevance of accounting information: Evidence from Iran. African Journal of Business Management, 5(1): 96-107.

Kommunuri, J., 2008. Value relevance of accounting information subsequent to the adoption of IFRS in New Zealand. Finance International Journal of Management Research, 5(8): 2005-2006.

Kothari, S.P. and J.L. Zimmerman, 1995. Price and return models. Journal of Accounting and Economics, 20(2): 155-192. DOI http://doi.org/10.1016/0165-4101(95)00399-4.

Kwong, L.C., 2010. The value relevance of financial reporting in Malaysia: Evidence from three different financial reporting periods. International Journal of Business and Accountancy, 1(1): 1-19.

Lang, M., R.J. Smith and W. Wilson, 2006. Earnings management and cross listing: Are reconciled earnings comparable to US earnings? Journal of Accounting and Economics, 42(1-2): 255-283. DOI http://doi.org/10.1016/j.jacceco.2006.04.005.

Liu, C., L.J. Yao and M.Y.M. Yao, 2012. Value relevance change under international accounting standards: An empirical study of Peru. Review of Pacific Basin Financial Markets \& Policies, 15(2): 1150008-1150017. DOI http://doi.org/10.1142/S0219091511500081. 
Mechelli, A. and R. Cimini, 2014. Is comprehensive income value relevant and does location matter? A European study. Accounting in Europe, 11(1): 59-87. DOI http://doi.org/10.1080/17449480.2014.890777.

Mironiuc, M., M. Carp and I.C. Chersan, 2015. The relevance of financial reporting on the performance of quoted Romanian companies in the context of adopting the IFRS. Procedia Economics and Finance, 20(15): 404-413. DOI http://doi.org/10.1016/S22125671(15)00090-8.

Mohammed, Y.A. and N.A. Lode, 2015. Value relevance of liabilities and non-performing loans in emerging market: IFRS adoption in Nigeria. In Bizmatour Conference, Malaka, Malaysia. pp: 98-103.

Mozes, H.A., 2002. The value relevance of financial institutions fair value disclosures : A study in the difficulty of linking unrealized gains and losses to equity values. Abacus, 38(1): 1-15.

Ohlson, J.A., 1995. Earnings, book values, and dividends in equity valuation. Contemporary Accounting Research, 11(2): 661-687.

Omokhudu, O.O. and P.O. Ibadin, 2015. The value relevance of accounting information: Evidence from Nigeria. Accounting and Finance Research, 4(3): 20-30. DOI http://doi.org/10.5430/afr.v4n3p20.

Palea, V., 2014. Are IFRS value-relevant for separate financial statements? Evidence from the Italian stock market. Journal of International Accounting, Auditing and Taxation, 23(1): 1-17. DOI http://doi.org/10.1016/j.intaccaudtax.2014.02.002.

Păşcan, I.D., 2015. Measuring the effects of IFRS adoption on accounting quality: A review. Procedia Economics and Finance, 32(15): 580587. DOI http://doi.org/10.1016/S2212-5671(15)01435-5.

Peter, E. and N. Nnorom, 2013. Reforms, stiff regulations buoy capital market activities in 2013. 1-36. Available from www.vanguarngr.comd/2013/12/.

Prather-Kinsey, J., 2006. Developing countries converging with developed-country accounting standards: Evidence from South Africa and Mexico. International Journal of Accounting, 41(2): 141-162. DOI http://doi.org/10.1016/j.intacc.2006.04.007.

Sule, M., D.A. Ismaila and H.M. Tahir, 2015. The efficacy of the random walk hypothesis in the Nigerian stock exchange market. European Journal of Business and Management, 9(26): 23-45.

Uthman, A.B. and Z. Abdul-Baki, 2014. The value-relevance of accounting information in Nigeria: Analysts perception in the IFRS regime. Journal of Accounting and Managements, 4(1): 43-60.

Vijitha, P. and B. Nimalathasan, 2014. Value relevance of accounting information and share price: A study of listed manufacturing companies in Sri Lanka. Merit Reserach Journals, 2(1): 1-6.

White, H., 1980. A heteroskedasticity-consistent covariance matrix estimator and a direct test for heteroskedasticity. Econometrica, 48(4): $817-838$. 